\title{
CORPORATE GOVERNANCE AND BUSINESS PERFORMANCE: THE MODERATING ROLE OF EXTERNAL AUDIT QUALITY
}

\author{
Wong Seng Foong1, Yuvaraj Ganesan 1, ${ }^{,}$, Anwar Allah Pitchay², Hasnah Haron ${ }^{3}$, Ratih Hendayani4 \\ ${ }^{1}$ Graduate School of Business, Universiti Sains Malaysia, Malaysia. \\ ${ }^{2}$ School of Management, Universiti Sains Malaysia, Malaysia. \\ ${ }^{3}$ Faculty of Industrial Management,Universiti Malaysia Pahang, Malaysia. \\ ${ }^{4}$ School of Economics and Business, Telkom University, Bandung, Indonesia.
}

ABSTRACT - The purpose of this study is to investigate the relationship of corporate governance attributes, i.e. board size, age diversity, risk management committee and internal audit function with the business performance of the organisation. In addition, this study also examines the role of external audit quality as a moderating effect in the relationship between corporate governance and business performance. The study adopted a quantitative approach and cross-sectional design where it used a sample of 120 listed companies in Malaysia for the year 2016. Data is collected based on secondary data which is annual report year 2016. The result shows board size and the existence of risk management committee are negatively significant related to business performance while the other variables such as age diversity and internal audit function do not have an impact on business performance. Unexpectedly, external audit quality does not play a moderating role in related corporate governance and business performance. The study contributes to the understanding of the relationship between corporate governance and business performance in the developing country. The paper also provides related insight for regulators, policymakers and investors of emerging markets such as Malaysia. The study is the pioneer to understand the relationship of the risk management committee to business performance and moderating effect of external audit quality.

ARTICLE HISTORY

Received: 23-03-2019

Accepted: 29-05-2019

\section{KEYWORDS}

Corporate governance, risk management committee, internal audit, external audit quality

\section{INTRODUCTION}

Numerous financial scandals around the world and the financial crisis has alerted companies and brought attention to the public and government on the importance of corporate governance. There are many financial scandals or companies failures around the world such as the Enron, WorldCom and event of financial crisis 1997 and 2008 which has caused the fall of Lehman Brothers one of the largest banks in the United States. Corporate governance has been an important factor for a firm to remain competitive at a global level (Ehikioya, 2009; Iwasaki, 2008). Corporate governance provides guidance to the company how they can be directed or controlled in order to strengthen the company process which ultimately brings good benefits to the company (Ehikioya, 2009). Good corporate governance is considered to be crucial to any company in order to have long term success and survive the financial crisis if it happened again. Good corporate governance practices can bring a positive effect on firm performance during the financial crisis of 2008 (Kowalewski, 2016).

In the year 1997, the Asian financial crisis has alarmed the Asia countries to pay attention to the reformation of corporate governance. Malaysia is one of the affected counties and basically all firms are not able to escape from the Asia financial crisis. Asia financial crisis in 1997 has caused Malaysia Kuala Lumpur Composite Index begins to plummet and in the year 1998 hits its lowest index of all time before the recovery stage. In the year 2007, the US market faces the subprime mortgage crisis which eventually leads to the collapse of Lehman Brothers in the year 2008. The effect of the US subprime crisis has eventually caused the global recession (Economywatch, 2010).

Malaysia has a corporate governance issue and one of the cases happened to be on 1Malaysia Development Berhad (1MDB). 1MDB has been accused of involving in controversies such as high debt, corruption and allegations against the state investment funds transfer over the third-party account and Malaysian Official One (MO1) account. There is also controversy over the appointment of a country's auditor-general to audit the financial account of 1MDB by Malaysia's former Prime Minister, YB Dato' Sri Mohd Najib bin Tun Abdul Razak and the independence of auditor-general is questioned. The 1MDB scandals affected the country's reputation, investor rational as well as the Malaysian people who are furious on this case. Weak corporate governance is a serious issue for 1MDB and the business performance is underperforming with having RM50 billion debts as of January 2016. 1MDB also dismissed the first two audit firms, Ernst \& Young and KPMG when the audit firms request for the investment documents (Blemin, 2015). Deloitte then took over the auditor position of 1MDB. However on 26 Feb 2016 Deloitte Malaysia has resigned as the auditor for 1MDB. 
Not long after resigned, Deloitte Malaysia has issued a statement stating the financial statement of 2013 and 2014 can no longer be relied upon. Based on the investigation of PAC (2016) on 1MDB found that the capital financing structure and financial performance are classified as "not satisfactory" due to its weak corporate governance.

Multi-factored reasons such as oil price weakening, 1MDB scandals and weak business performance have an effect on the economy of Malaysia and the particular effect will be a weakening of the currency and the country's reputation. The incidents including weak corporate governance have created a chain of the problem and affected the business performance of Malaysia. Based on the statistics conducted by the DOSM (2017), the expected overall business performance of Malaysia in 2016, decreased 1.4 percent while the first quarter of 2017 is expected to decrease by 6.9 percent. The senior management in the four major sectors in Malaysia namely industry, construction, wholesale \& retail trade and services are not optimistic about the business performance in Malaysia (DOSM, 2017).

In 2017, the former executive directors of Welli Multi Corporation Bhd have been found guilty for providing a misleading financial statement and face fines of RM400,000 and sentence of 6 months jail. The directors have provided misleading revenue figures involving over RM141 million in fictitious sales in Welli Multi's 2005 annual report, reporting a profit of RM5 million when in fact it was facing a loss of RM35 million (Aziz, 2017; SCM, 2017). This has not been the only case in Malaysia for the year 2017, former Executive Chairman of Megan Media Holdings and Former Independent Directors of Transmile Group Bhd have also been found guilty in providing false or misleading statements (SCM, 2017).

Although the business performance of companies appears to be good, it also raised doubt whether it is true that the companies have performed as shown in the figure that have been disclosed. Internal and external auditors also played an important role in overseeing the control of the company which will influence the business performance. External auditors are generally considered to be more independent and many fraud cases can be prevented if the external audit quality is strong and sound. Besides that, the external auditor can improve the reputation and the reliability of the financial statement of the company.

This paper aims to investigate the relationship between corporate governance attributes (board size, age diversity, risk management committee and internal audit function) and business performance. Besides that, the study also intends to determine the moderator effect of external audit quality between corporate governance attributes and business performance.

\section{LITERATURE REVIEW}

Business performance and corporate governance appear to be the general concern among corporations, investors, regulators, researchers and stakeholders. In Malaysia, Bank Rakyat Chairman Datuk Harun bin Idris has misused the bank funds of \$7.5 million in the year 1975. In the year 1983, Bumiputra Malaysia Finance (BMF) has suffered a loss of \$2.5 billion because of giving out unsecured loans or secured loan with overstated asset value. The directors of BMF has received bribes in order to approve such big and many amounts of loans. Board of Directors are the highest management of one company, therefore, the number of directors or the size of the board are largely discussed. It is one of the important factors that has contributed to business success. Board size is defined as the total number of directors on the company board or the number of board of directors (Levrau \& Van den Berghe, 2007; Panasian, Prevost, \& Bhabra, 2003). Director age may have influences on business performance, higher age of director may signal experience, resources, network in the company or industry which can improve business performance. Age is a standard or benchmark for the extent of experience and a signal of a person's intention to risk-taking (Herrmann \& Datta, 2005). Meanwhile, a risk management committee is a unit in the company which is responsible for supervisory duties in company risk management activities. Risk management committee oversees the key risk area on the senior management activities and ensures the company has an appropriate risk management initiative in the company (Malaysia, 2010). Indeed internal audit sees its role as an independent and objective mechanism to add value and assurance to the company (IIARF, 2013). Internal audit function is typically involved as a consultant, instead of being directly involved in the management of the company (Mohamed, Mat Zain, Subramaniam, Yusoff, \& Fadzilah, 2012). Carey, Subramaniam, and Ching (2006) states that internal audit activities are the core business or competencies of external service provider therefore with a large amount of customer using their service they are able to create economies of scale. Knechel, Krishnan, Pevzner, Shefchik, and Velury (2012) define audit quality as the execution of a good design audit process by experienced auditors who understand the condition and uncertainty of the situation well. On the other hand, external audit quality refers to the audit quality performed by the external auditor. Performance is illustrated as the process of an individual or groups to achieve the goals and objectives while indirectly business performance is defined as how an organization managed its employees to achieve the business objectives (Yıldız, Baştürk, \& Boz, 2014).

\section{Agency Theory}

In most of the corporate governance study, agency theories are the most fundamental theories of all. Agency theory was developed by Alchian and Demsetz (1972) and it was then revised by Jensen and Meckling (1976). Agency theory explains the relationship between the principal and the agents. The principals refer to the company's owner or the shareholders while the agents are the manager or company senior management. The owner or the principal hires and the agent or managers to run the company. The shareholder's agent who are the manager or director are delegated by the principal or shareholder to run the business or the company (Clarke, 2004). In agency theory, the agents or director or manager are expected to make a decision based on the interest of the principal or shareholders. However, according to 
Padilla (2002), the agents are not expected to make a decision totally according to the principal's interest. The conflict of interest between the agents and the principals are confirmed by multiple authors such as Davis, Schoorman, and Donaldson (1997), Jensen and Meckling (1976) and Ross (1973). Agency problem arises where there is a separation of ownership, it leads to the managers or directors do not perform an action to maximize shareholder's wealth instead they tend to action based on self-interest.

\section{Theoretical Framework}

The theoretical framework in Figure 1 is based on agency theory to explain the relationship of corporate governance attributes (board size, age diversity, risk management committee and internal audit function) to business performance. Agency theory explains the relationship between the principal and the agents. Besides that, the framework also explains the extent of the moderating effect of External Audit Quality to the relationship between corporate governance attributes and business performance.

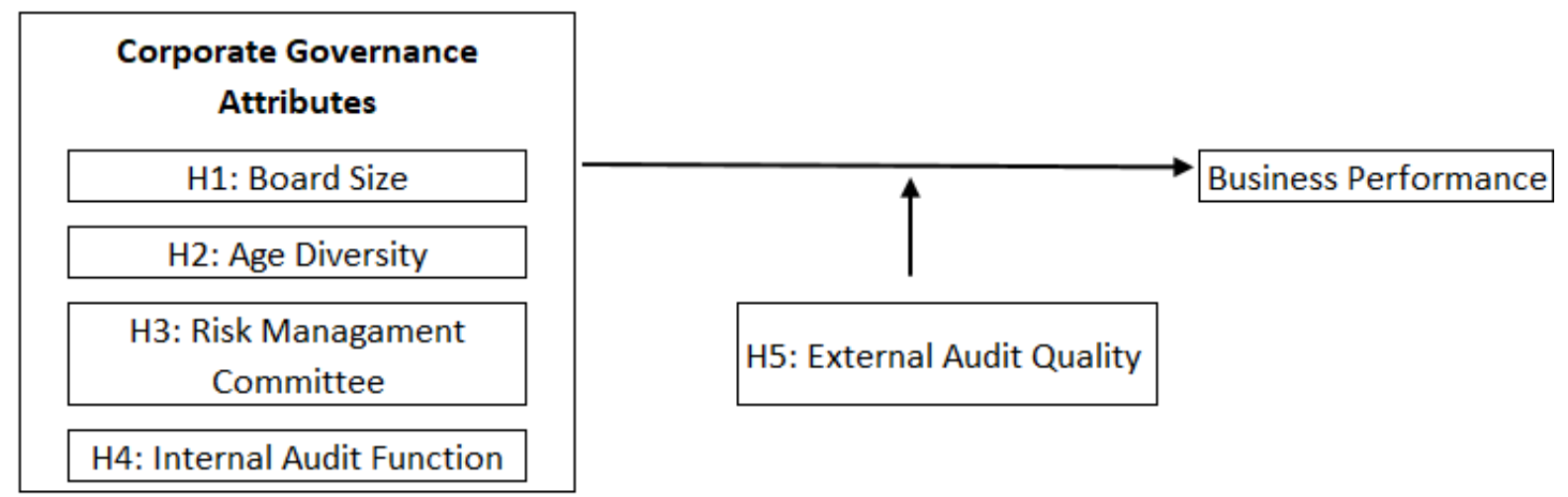

Figure 1: Theoretical Framework of the study

\section{The Relationship between Board Size (BS) and Business Performance (BP)}

Based on agency theory, the firm performance is better with a smaller board size as the managers are not acting in the best interest of the shareholders. Some literature has found to have a consistency to the agency theory perspectives that smaller board size is positively related to business performance (Denis \& Sarin, 1999; Eisenberg, Sundgren, \& Wells, 1998; Gertner \& Kaplan, 1996; Yermack, 1996). Gertner and Kaplan (1996) stated smaller board size is preferred by shareholder mainly due to the cost incurred and prevent free riders problems appear in the board. In the study of Yermack (1996), Tobin's Q was used as the measurement for firm value, the result showed smaller board leads to better financial ratios and CEO compensations are better as well. According to the study of Zabri, Ahmad, and Wah (2016), ROA and ROE are used as the indicator to measure firm performance and the study found outboard size is insignificant to ROE while it has a weak negative relationship with ROA. Based on the above literature, the following hypothesis is proposed:

$\mathrm{H} 1$ :Board size is negatively related to business performance.

\section{The Relationship between Age Diversity (Age) and Business Performance (BP)}

Based on the finding of limited studies on the relationship between director age and business performance, the result is not consistent. The studies from multiples authors show a negative relationship between age diversity and business performance (Kunze, Boehm, \& Bruch, 2011; Milliken \& Martins, 1996). This is also supported by the study of Faleye (2007) where the results reported a negative and significant relationship between age diversity (average director's age) and firm value measured by Tobin's Q. Based on the findings from Bunderson and Sutcliffe (2002) and Zimmerman (2008), there is no significant relationship between age diversity and business performance. The findings are supported by the study of Randøy, Thomsen, and Oxelheim (2006) in the context of Norway, Sweden and Denmark.

On the other hand, the relationship between age diversity and business performance are positively related to each other (Helen, Mandy, \& Sidney, 2007; Kilduff, Reinhard, \& Mehra, 2000). The study of Ararat, Aksu, and Tansel Cetin (2010) and Mahadeo, Soobaroyen, and Hanuman (2012) have the same findings there is a positive relationship between age diversity and business performance in the context of Turkey and Mauritius. Based on the above discussion, the following hypothesis is proposed:

H2:Age Diversity is positively related to business performance.

\section{The Relationship between Risk Management Committee (RMC) and Business Performance (BP)}

There are limited studies exploring the aspect of the risk management committee. However, there is some literature on risk management. A study by Saeidi, Sofian, and Rasid (2014) found that Enterprise Risk Management is positively related to business performance because Enterprise risk management brings value to stakeholders, improve the company competitive advantage and performance and increase the ability to achieve organization goals. Furthermore, based on 
the research by $\mathrm{Mu}$, Peng, and MacLachlan (2009) risk management is positively related to business performance and also the performance of new product development. As a contrast, Matthews (2013) argues that there is no significant relationship between modern risk management methods developed by a Chinese bank to business performance using a financial measure such as ROA.

Based on the findings of Aebi, Sabato, and Schmid (2012), the presence of a Chief Risk Officer (CRO) in the board and the situation where the CRO directly reported to boards are positively related to business performance. In addition, Kao, Lin, Hsu, and Chen (2011) found that risk management leads positive effect to operational efficiency for the financial holding company in other words risk management is positively related to business performance as the operation is running efficiently. In the same tone, Hadad, Hall, Kenjegalieva, Santoso, and Simper (2011) and Cummins and Weiss (2013) indicated the risk management is able to improve the productivity and efficiency of financial related companies.

Based on the above discussion risk management is positively influence business performance. However, studies exploring in particularly on the relationship of the risk management committee and business performance is limited. In the context of Malaysia, the company may subject to political influence, therefore, there may be inexperienced director being appointed as the committee member of the risk management committee. Furthermore, risk management appears to be one of the responsibilities of the internal audit function and there may cause roles duplication between risk management committee and audit committee, therefore, the study hypothesized:

H3:Risk Management Committee is negatively related to business performance.

\section{The Relationship between Internal Audit function (IAF) and Business Performance (BP)}

In the recent study of Nyameboame and Haddud (2017), outsourcing resources and service gives significant financial benefits for locally owned oil and gas companies. The study stated a combination of cost reduction, better access to technology and expertise, the capability of outsourcers to handle the company's core issue have led to a better financial performance of the organization. The findings are supported by the empirical research of Jiang, Frazier, and Prater (2006) there is evidence shown that outsourcing improved cost efficiency of the company, however, remains non-significant on productivity and profitability. However, in the research of Solakivi, Töyli, Engblom, and Ojala (2011) found that no significant relationship between outsourcing and the cost for logistic level, therefore, it has no gain or loss from a financial perspective.

Nagy and Cenker (2002) find that internal audit function varies significantly among firms from a traditional assurance orientation to a value-added and consulting orientation with most firms landing in between traditional and consulting. Ruud (2003) argues that in today's business environment, the internal audit function has become a major support function for management, the audit committee, the board of directors, the external auditors and other stakeholders. Australian firms are associated with a commitment to strong risk management and firm size with the use of internal audit function. (Goodwin-Stewart \& Kent, 2006). In the study of Carcello, Hermanson, and Raghunandan (2005) US public firms' investment in internal audit showed that total internal audit budgets are positively related to company size, leverage, financial, service, and utility industries, relative amount of inventory, operating cash flows, and audit committee's review of the internal audit budget. Therefore based on the discussion, the following hypothesis is proposed:

H4:Internal Audit function (outsource) is positively related to business performance.

\section{The moderator effect of external audit quality (EAQ) between corporate governance attributes and business performance}

Based on previous studies, there are inconsistencies on the result related to corporate governance attributes and business performance. Therefore this study introduced external audit quality as the moderator. Based on the research of Fuerman (2003), the study found that the Big Six audit firm produced higher quality auditor as compared to non-Big Six audit firm. The large audit firm is likely to discover earning management because of their expert knowledge and motivation to protect its reputation (Becker, DeFond, Jiambalvo, \& Subramanyam, 1998). Based on capital market studies, the stock market is positively influenced by the switch larger audit firm to a company and the response for earning coefficient are also higher for a company with large audit firm (Teoh \& Wong, 1993). On the other hand, Jang and Lin (1993) found out during the initial public offering (IPO) event, the volume of stock with Big Eight Audit firm is significantly higher than the stock with the smaller audit firm. In the same aspect, the IPO will experience more reasonable pricing when they use the service of big audit firms (Firth \& Smith, 1992).

However, this raises a question that if the larger firm has better audit quality then why there are lots of big corporate failure or scandal such as Enron. This is supported by the empirical research by Eisenberg and Macey (2004) and Tilis (2005) where the studies show no evidence of audit quality differentials among large audit firm based on the earning restatement data. Furthermore, the majority of studies or views support audit firm size represents the audit quality however there is a lack of support or studies on the differentiation of large audit firm quality.

Audit quality is a latent variable or hidden variable that cannot be directly measured. Based on previous studies, researchers have used different substitutes as the measurement of audit quality such as audit engagement tenure Al-Ajmi (2009), audit structure (Kaplan, Menon, \& Williams, 1990), audit fees (Hassan, Abdul, \& Mahenthiran, 2008), auditor industrial experience (Lowensohn, Johnson, Elder, \& Davies, 2007) and lawsuit case against company and audit firm (Schmidt, 2012). Meanwhile, the most common proxy of audit quality is audit firm size which has been adopted by multiple authors (DeFond \& Lennox, 2011; Fernando, Abdel-Meguid, \& Elder, 2010; Kim, Song, \& Tsui, 2013; Sundgren \& Svanström, 2013). 
In support Sundgren and Svanström (2013) pointed out that a larger firm commonly has more resources and technically more knowledgeable than the smaller firm. Besides that, a study by Sundgren and Svanström (2014) concludes that smaller firms are likely to omit critical audit procedures when the workload is high such as during peak or high volume season. This is also agreed by various researchers that the size of an audit firm is positively related to the audit quality and the monitoring capability (Al-Ajmi, 2009; Jang \& Lin, 1993; Leuz \& Verrecchia, 2000). Based on the literature, it has been hypothesized as per below:

H5(a) External audit quality moderates the relationship between board size and business performance.

H5(b) External audit quality moderates the relationship between Age Diversity and business performance.

H5(c) External audit quality moderates the relationship between Risk Management Committee and business performance.

H5(d) External audit quality moderates the relationship between Internal Audit Function(outsource) and business performance.

\section{METHODOLOGY}

This study applies a quantitative approach with secondary data and adopted cross-sectional design. The population of this study is the public listed companies in Bursa Malaysia. However, financial sectors will be excluded in this study because financial companies are subject to the different requirement, rules and regulations required by the Bank Negara Malaysia (Devi, Hooper, Uddin, \& Tsamenyi, 2011). The unit analysis of this study is a firm. This study was adopted adopt non-probability sampling as the companies are selected based on top 120 market capitalization indicated in DataStream excluding financial companies as of 31 Dec 2016. The reason for selecting big size companies because the area of effect is considerably larger than small companies if there is corporate governance failure. This is also supported by the study of other researchers where the studies found that the activity of large companies are having a strong effect on the community (Ghazali \& Weetman, 2006; Haniffa \& Cooke, 2005).

This study utilize secondary data extracted from the annual report (financial ended year 2016) of the selected 120 companies in Bursa Malaysia. The measurements of variables of study shown in table 1.

Table 1: Measurement of variables

\begin{tabular}{|c|c|c|}
\hline Variables & Measurement & Sources \\
\hline $\begin{array}{l}\text { Business } \\
\text { Performance (BP) }\end{array}$ & Return on asset (ROA) & $\begin{array}{l}\text { Bhatt and Bhatt (2017); Solakoglu } \\
\text { and Demir (2016); Zabri et al. } \\
\text { (2016) }\end{array}$ \\
\hline Board Size (BS) & The total number of board directors & $\begin{array}{l}\text { Zabri et al. (2016); } \\
\text { Johl, Kaur, and Cooper (2015); } \\
\text { Otman (2014) }\end{array}$ \\
\hline Age Diversity (Age) & $\begin{array}{l}\text { The coefficient of variation to measure the age } \\
\text { diversity by dividing the standard deviation of board } \\
\text { members' age by the mean of their age }\end{array}$ & $\begin{array}{l}\text { Xu, Zhang, and Chen } \\
\text { (2017);Shehata, Salhin, and El- } \\
\text { Helaly (2017);Ali, Ng, and Kulik } \\
\text { (2014) }\end{array}$ \\
\hline $\begin{array}{l}\text { Risk Management } \\
\text { Committee (RMC) }\end{array}$ & $\begin{array}{l}\text { Binary variable where " } 1 \text { " indicates companies have } \\
\text { risk management committee and " } 0 \text { " indicates the } \\
\text { company does not have a risk management } \\
\text { committee }\end{array}$ & Yatim $(2010)$ \\
\hline $\begin{array}{l}\text { Internal Audit } \\
\text { Function (IAF) }\end{array}$ & $\begin{array}{l}\text { Binary variable where " } 1 \text { " indicates some or all } \\
\text { internal audit activities are outsourced and "0" } \\
\text { indicates internal audit activities performed in-house }\end{array}$ & Carey et al. (2006) \\
\hline $\begin{array}{l}\text { External Audit } \\
\text { Quality (EAQ) }\end{array}$ & $\begin{array}{l}\text { Binary variable where " } 1 \text { " is coded for external } \\
\text { auditors are from BIG } 4 \text { audit firm, " } 0 \text { " for company } \\
\text { does not use BIG } 4 \text { as their external auditor }\end{array}$ & $\begin{array}{l}\text { Gaaya et al. (2017); Han, Kang, } \\
\text { and Rees (2013); Nnadi, Efobi, and } \\
\text { Oledinma (2017). }\end{array}$ \\
\hline Firm Size (FS) & $\begin{array}{l}\text { The natural logarithm of market capitalization at the } \\
\text { beginning of the year }\end{array}$ & $\begin{array}{l}\text { Dhaliwal, Naiker, and Navissi } \\
\text { (2006); Sil Kang, Kilgore, and } \\
\text { Wright (2011) }\end{array}$ \\
\hline
\end{tabular}




\section{RESULTS}

The frequency analysis highlighted that from 120 companies, majority companies have a board size of $8-9$ number of directors and it contributes to 42 percent of the total companies. Meanwhile, 81 companies have a risk management committee while the remaining 39 companies do not have a risk management committee in the company. On other hand, a majority of 98 companies used in-house internal audit while the other 22 companies opt for outsourcing. Further, $85 \%$ sample companies used big 4 as their external auditor while only 18 companies used non-big 4 companies as their external auditor.

The data analysis in Smart PLS 3.0 shown that all inner VIF value for independent variables are less than 5 as recommended by Hair Jr, Hult, Ringle, and Sarstedt (2016), therefore, this indicates lateral multicollinearity is not a concern in the study. The study model has the ability to explain 10.2 percent of the variance in independent variables on business performance. Further, the effect size for board size and risk management committee are small. In addition, the model have predictive relevance as the value of Q2 above zero as showed in table 2.

Bootstrapping function whereby the threshold used is based on the one-tailed test for a direct approach. Based on the assessment of the path coefficient as depicted in Table 2, only Board Size $(\beta=-0.257, p<0.01)$ and Risk Management Committee $(\beta=-0181, p<0.05)$ are negatively significant with Business Performance. Thus, as expectedly the H1 and H3 are supported. Surprisingly, H2 and H4 not supported. The result shown that age diversity and internal audit function not influence the business performance.

Table 2: Hypothesis Testing

\begin{tabular}{|c|c|c|c|c|c|c|c|c|}
\hline $\begin{array}{l}\text { Hypo- } \\
\text { theses }\end{array}$ & Relationship & $\begin{array}{c}\text { Std. Beta } \\
(\beta)\end{array}$ & $\begin{array}{l}\text { Std. } \\
\text { Error }\end{array}$ & t-value & Decision & $\mathbf{R}^{2}$ & $\mathbf{f}^{2}$ & $\mathbf{Q}^{2}$ \\
\hline $\mathrm{H} 1$ & BS -> BP & -0.257 & 0.06 & $4.282 * *$ & Supported & 0.102 & 0.070 & 0.021 \\
\hline $\mathrm{H} 2$ & Age $->$ BP & 0.035 & 0.075 & 0.463 & $\begin{array}{c}\text { Not } \\
\text { Supported }\end{array}$ & & 0.001 & \\
\hline H3 & $\mathrm{RMC}_{-}>\mathrm{BP}$ & -0.181 & 0.102 & $1.772 *$ & Supported & & 0.031 & \\
\hline $\mathrm{H} 4$ & IAF -> BP & 0.014 & 0.08 & 0.175 & $\begin{array}{c}\text { Not } \\
\text { Supported }\end{array}$ & & 0.0002 & \\
\hline
\end{tabular}

Note: $* \mathrm{p}<0.05, * * \mathrm{p}<0.01$

\section{Testing the Moderating Effect}

Table 3: Path Coefficient and t-value for Independent Variables with Moderating Effect

\begin{tabular}{|c|c|c|c|c|c|c|}
\hline $\begin{array}{l}\text { Hypo- } \\
\text { theses }\end{array}$ & Relationship & Std. Beta $(\beta)$ & $\begin{array}{c}\text { Std. } \\
\text { Error }\end{array}$ & t-value & Decision & $\mathbf{R}^{2}$ \\
\hline H5(a) & $\mathrm{BS}^{*} \mathrm{EAQ} \rightarrow \mathrm{BP}$ & -0.078 & 0.073 & 1.063 & Not Supported & 0.113 \\
\hline H5(b) & $\mathrm{Age}^{*} \mathrm{EAQ} \rightarrow \mathrm{BP}$ & -0.028 & 0.083 & 0.333 & Not Supported & \\
\hline H5(c) & $\mathrm{RMC} * \mathrm{EAQ} \rightarrow \mathrm{BP}$ & -0.069 & 0.079 & 0.876 & Not Supported & \\
\hline H5(d) & $\mathrm{IAF}^{*} \mathrm{EAQ} \rightarrow \mathrm{BP}$ & -0.018 & 0.214 & 0.083 & Not Supported & \\
\hline
\end{tabular}

Note: $* \mathrm{p}<0.05, * * \mathrm{p}<0.01$

Table 3 summarizes the path coefficient, t-value for each independent variables to a dependent variable relationship with moderating effect. Based on the result, unexpectedly all the hypotheses are statistically insignificant therefore H5(a), H5(b), H5(c) and H5(d) are not supported. However, the comparison of Coefficient of Determination $\mathrm{R}^{\wedge} 2$ without and with External Audit Quality as Moderating effect depicted that $\mathrm{R}^{\wedge} 2$ of moderating effect is 0.113 implies that $11.3 \%$ variance of business performance is explained by the model. $\mathrm{R}^{\wedge} 2$ changed 0.011 which indicated an increase of $1.1 \%$ invariance.

\section{DISCUSSION}

The result revealed that board size is negatively related to business performance. This result is consistent with prior US studies for 1252 firm (Cheng, 2008). When the board size grows bigger the agency problem becomes bigger. The directors generally do not criticize the way of top management or expert method in handling company and the problem is bigger with the larger board because the cost of any individual director of not doing the duty of monitoring the management is in proportion to the total number of board directors (Lipton \& Lorsch, 1992). Jensen (1993) states that when a board has more than seven or eight it will have a communication problem, less efficient and slow in decision making. In Malaysia, the study notices some of the family-owned companies hire their family members as a board of directors, some are relatively young, and this shows that the directors may not have sufficient knowledge and experience 
to question or monitor the top management. Lastly bigger board size may have a bigger possibility to have a free rider problem where it is not beneficial to the company and consumed company resources. On other hand, this study shown that age diversity does not influence the business performance. The result is consistent with the prior studies from Bunderson and Sutcliffe (2002) and Zimmerman (2008), there is no significant relationship between age diversity and business performance. The findings are also supported by the study of Randøy et al. (2006) in the context of Norway, Sweden and Denmark. The samples selected in this study are top 120 market capitalization companies in Bursa Malaysia this indicates that the companies are relatively big enough to hire a top expert in their related industries. When the companies rely on top managers, the experience of older director and creativity of younger director may not be able to contribute to the business performance.

Meanwhile, the finding reveals the existence of the risk management committee is negatively related to business performance. Due to limited studies particularly on risk management committee supported with justification, the negative direction has been indicated in the hypothesis. Prior studies generally draw a conclusion of risk management is positively related to business performance but not risk management committee. Based on the findings, the existence of risk management committee is harmful to business performance may be because of the risk prevention measure is costly and it may not directly add value or reflect onto business financial figures and business performance. Besides that, the risk management committee is not mandatory to establish, and it can be new to some companies. There may be a possibility of having ambiguous or duplicated responsibilities between the audit committee and risk management committee which may cause inefficient resource allocation. Conversely, internal audit functions are not able to affect the business performance. In the study of Carey et al. (2006) finds that cost saving and technical expertise of the external service provider are the main reason for choosing outsourcing internal audit function. However, in the selected sample, all companies are big companies and outsourcing may have more benefits in cost compared to own internal audit department however the cost may be too little to create an impact to company's ROA.

The moderating analysis portrays surprising finding as external audit quality does not play moderating role in this study. The finding shows that there is no significant moderating effect in the relationship between board size and business performance. Previous studies showed that there are arguments for and against bigger board size positively affects the business. However, external auditors are hired by the company and generally play a role to perform an audit to company financial statement where they have no or little impact on to company's profitability. The business performance will still depend on the external resources brought in by the board, therefore whether big 4 or non-big 4 audit firm does not moderate the relationship between board size and business performance. In addition, external audit quality also does not moderate the relationship between age diversity and business performance. Based on previous studies there is no consistent result on the relationship between age diversity and business performance. There are authors support and against age diversity and some authors found that there are no significant between age diversity and business performance. Older directors may provide experience and network to resource to the company while younger directors may be more risk-taking and creative however business performance still largely depends on the management or experts. Director's age diversity may not be decisive on the business performance, therefore external audit quality does not have a moderating effect on the relationship between age diversity and business performance.

Besides that, the result highlighted that the external audit quality does not have moderating effect in the relationship between the risk management committee and business performance. It could be due to risk management committee supervises and oversees the company's risk management policies and activity. The risk measures applied may not provide a direct effect on business performance or it may increase cost due to expensive preventive measures. External auditors are responsible for financial statement auditing and external audit quality does not influence the activities of a risk management committee, therefore, the result shows that external audit quality does not moderate the relationship between risk management committee and business performance. Furthermore, unpredicted the external audit quality does not play moderating role in the relationship between internal audit function and business performance although in some cases external auditor were reliance on the work of internal auditor. The unexpected result due to the outsourcing internal audit function is more cost effective if compared to in-house internal audit however if the company is big and internal audit activity is high in-house internal audit may be a better option due to economic of scale. External auditors can rely on the work of internal auditors because internal auditors are more familiar with the internal process therefore at some point the opinion from internal and external auditors can be the same. Besides that, the internal audit department from the big corporation can be well qualified and adhered to strict policy. Therefore, the moderating effect of external audit quality appears to be not significant to the relationship between internal audit function and business performance.

\section{CONCLUSION AND IMPLICATIONS}

Business performance is considered as one of the most important factors that contribute to economic and organization success. All stakeholders such as shareholders, managers, employees, supplier, buyer and government always keep an eye on business performance as it brings large impacts to many parties. The collective business performance will impact the country's economy and individual business performance will have influences on many aspects and people depending on the size of the company. Corporate governance appears to be one of the determinants of business performance. Corporate governance is always the spotlight of all public, government and regulators because it helps to maintain the sustainability of the company and balance the interest of the company's stakeholders. Corporate governance gets even more attention when there are corporate failures, poor financial performance and financial scandals. It guides the company to follow a set of rules, practice and requirement to fortify the strength and stability of the company. In Malaysia, all 
public listed companies are required to comply with Malaysia Code on Corporate Governance as introduced by the Securities Commission Malaysia.

This study aims to investigate the relationship between corporate governance attributes, such as Board Size, Age Diversity, Risk Management Committee and Internal Audit Function with the business performance. Second, the study intends to find out the moderating effect of external audit quality to the relationship of corporate governance and business performance. The sample used for this study is 120 top market capitalization public listed companies in Bursa Malaysia as generally based on the size of the companies they will have a bigger influence towards public or country if the company fails. Four independent variables (board size, age diversity, risk management committee, internal audit function), one dependent variable (business performance) and one moderator (external audit quality) are tested with PLS. This study contributes to the literature of agency theory and corporate governance towards business performance. The result of the study supports agency problem point of view that the board or committee member may act on self-interest more instead of company interest. Practically, the findings serve as a reference to the policy maker, investors and researcher.

The results showed that board size and risk management committee have a negative significant effect on business performance. When the board size gets bigger the company may have free riders' issue and some companies appointed their family members as the board directors which may seem to contribute ineffectively to the company from the public point of view. These big companies normally hire a top expert to manage the companies, the directors rarely question on policies taken by the management and therefore the cost of individual directors does not perform the duty to monitor the management becomes bigger. The establishment of the risk management committee may have caused ineffective resource utilization or wastage as there may be duplication in responsibilities between the risk management committee and audit committee. Besides that, risk management and risk preventive implementation can be costly, and it does not directly reflect the benefit into business performance.

The study enhances the literature of corporate governance attributes and business performance in the context of Malaysia public listed companies. The findings such as board size and risk management committee are significantly and negatively related to business performance will contribute to the literature of agency theory based on Malaysia environment that the board of directors and committee members may act on self-interest instead of company interest. Further, some practical implication derived from the research and it can be beneficial to an organization, investors or stakeholders. The finding shows that board size and risk management Committee are negatively and significantly related to business performance. Organization especially the big companies may take the findings and review on the number of board members and the necessary on the establishment of risk management committee although it is one of the steps up approach in MCCG 2017. Investors may utilize the statistical data and result that are disclosed in this study and take the following idea into their investing decision. Other researchers and stakeholders may also make use of the study to understand more on the corporate governance strength on business performance in Malaysia market. Lastly, policymaker can utilize the result to review its current policy on board size and the establishment of a risk management committee.

\section{RELATED WORK}

This part provides a brief overview of optimization algorithms followed by the application of OBL in optimization algorithms. Some of optimization algorithms are based on population-based where the search process is perform with multiple agents. One example of population-based optimization algorithm is particle swarm optimization (PSO). In PSO, a swarm of agent searches for the global optimum solution by velocity and position updates, which are depending on current position of agent, personal best, and global best of the swarm. They move towards those particles which have better fitness values and finally attain the best solution.

Another population-based optimization algorithm is gravitational search algorithm (GSA). GSA was designed according to the Newtonian gravity law and mass interactions. In the algorithm, agents and their performance is evaluated by their masses which rely on fitness function values. The location of each agent in the search space indicates a problem solution. The heaviest mass is the optimum solution in the search space and by lapse of time, masses are attracted by the heaviest mass and converged to the better solution.

The concept of opposition-based learning is applicable to a wide range of optimization algorithms. Even though the proposed approach is originally embedded in differential evolution (DE), it is universal enough to be employed in other optimization algorithms. In (Huang et al., 2018), the OBL has been used to accelerate the convergence rate of DE. The proposed opposition-based DE (ODE) implements the OBL at population initialization and also for generation jumping. Besides that, a comprehensive investigation was conducted by using 58 benchmark functions with a purpose to analyze the effectiveness of ODE. Various sets of experiments are performed separately to examine the influence of opposite points, dimensionality, population size and jumping rates on the ODE algorithm.

Opposition-based differential evolution using the current optimum (COODE) was introduced for function optimization. In the COODE, the optimum agent in the current population is dynamically functioned as the symmetry point between an estimate and its respective opposite estimate. The distance between opposite numbers and the global optimum is short enough to maintain a significant rate of applying OBL throughout the search process.

Opposition-based particle swarm optimization (OPSO) is proposed by employing OBL to population initialization, generation jumping and the swarm's best particle. Initially, swarms are initialized with random velocities and positions. The opposite swarm is determined by calculating the opposite of velocity and position, and then the fittest of swarm and opposite swarm is chosen as the next population. The similar approach is used in current generations by applying jumping rate and dynamic constriction factor, which is used to improve the convergence rate. 
In other report, the OBL technique has been used to enhance the quality of solutions and convergence rate of an ant colony system (ACS). Five versions of implementing opposition idea have been proposed to extend the solution construction phase of ACS, known as, free opposition, free quasi-opposition, synchronous opposition, opposite pheromone per node (OPN) and opposite pheromone per edge (OPE). Results of these algorithms on TSP problems indicate that only OPN technique shows significant improvement.

\section{REFERENCES}

Caccese, J. B., Buckley, T. A., Tierney, R. T., Arbogast, K. B., Rose, W. C., Glutting, J. J., \& Kaminski, T. W. (2018). Head and neck size and neck strength predict linear and rotational acceleration during purposeful soccer heading. Sports Biomechanics, 17(4), 462-476. https://doi.org/10.1080/14763141.2017.1360385

Huang, X., Sun, J., \& Sun, J. (2018). A car-following model considering asymmetric driving behavior based on long short-term memory neuralAebi, V., Sabato, G., \& Schmid, M. (2012). Risk management, corporate governance, and bank performance in the financial crisis. Journal of Banking \& Finance, 36(12), 3213-3226.

Al-Ajmi, J. (2009). Audit firm, corporate governance, and audit quality: Evidence from Bahrain. Advances in accounting, 25(1), 6474.

Alchian, A. A., \& Demsetz, H. (1972). Production, information costs, and economic organization. The American economic review, 62(5), 777-795.

Ali, M., Ng, Y. L., \& Kulik, C. T. (2014). Board age and gender diversity: A test of competing linear and curvilinear predictions. Journal of Business Ethics, 125(3), 497-512.

Ararat, M., Aksu, M. H., \& Tansel Cetin, A. (2010). The impact of board diversity on boards' monitoring intensity and firm performance: evidence from the Istanbul Stock Exchange.

Aziz, A. (2017). SC wins appeal to extend jail term for ex-Welli Multi directors. The Edge Markets. Retrieved from http://www.theedgemarkets.com/article/sc-wins-appeal-extend-jail-term-exwelli-multi-directors

Becker, C. L., DeFond, M. L., Jiambalvo, J., \& Subramanyam, K. (1998). The effect of audit quality on earnings management. Contemporary accounting research, 15(1), 1-24.

Bhatt, P. R., \& Bhatt, R. R. (2017). Corporate governance and firm performance in Malaysia. Corporate Governance: The international journal of business in society, 17(5), 896-912.

Blemin, C. (2015). Malaysia's 1MDB sacked two auditors, EY and KPMG, in four years. The Edge Markets. Retrieved from http://www.theedgemarkets.com/article/malaysias-1mdb-sacked-two-auditors-ey-and-kpmg-four-years

Bunderson, J. S., \& Sutcliffe, K. M. (2002). Comparing alternative conceptualizations of functional diversity in management teams: Process and performance effects. Academy of management journal, 45(5), 875-893.

Carcello, J. V., Hermanson, D. R., \& Raghunandan, K. (2005). Factors associated with US public companies' investment in internal auditing. Accounting Horizons, 19(2), 69-84.

Carey, P., Subramaniam, N., \& Ching, K. C. W. (2006). Internal audit outsourcing in Australia. Accounting \& Finance, 46(1), 11-30.

Cheng, S. (2008). Board size and the variability of corporate performance. Journal of financial economics, 87(1), 157-176.

Clarke, T. (2004). Theories of Corporate Governance: The Philosophical Foundations of Corporate Governance. London: Taylor and Francis.

Cummins, J., \& Weiss, M. (2013). Analyzing firm performance in the insurance industry using frontier efficiency and productivity methods. New York: Springer.

Davis, J. H., Schoorman, F. D., \& Donaldson, L. (1997). Toward a stewardship theory of management. Academy of Management review, 22(1), 20-47.

DeFond, M. L., \& Lennox, C. S. (2011). The effect of SOX on small auditor exits and audit quality. Journal of Accounting and Economics, 52(1), 21-40.

Denis, D. J., \& Sarin, A. (1999). Ownership and board structures in publicly traded corporations. Journal of financial economics, 52(2), 187-223.

Devi, S. S., Hooper, K., Uddin, S., \& Tsamenyi, M. (2011). Accounting in Asia: Emerald Group Publishing.

Dhaliwal, D. S., Naiker, V., \& Navissi, F. (2006). Audit committee financial expertise, corporate governance and accruals quality: An empirical analysis.

DOSM. (2017). Business Tendency Statistics First Quarter 2017 [Press release]. Retrieved from https://www.dosm.gov.my/v1/index.php?r=column/cthemeByCat\&cat=150\&bul_id=SmpVV2RoSjY0T1hJWnhPMTVIN1Ex dz09\&menu_id=YmJrMEFKT0p0WUIxbD11bzZydW9JQT09

Economywatch. (2010). Global Recession due to US Subprime Crisis. Retrieved from http://www.economywatch.com/ussubprime/global-recession.html

Ehikioya, B. I. (2009). Corporate governance structure and firm performance in developing economies: evidence from Nigeria. Corporate Governance: The international journal of business in society, 9(3), 231-243.

Eisenberg, T., \& Macey, J. R. (2004). Was Arthur Andersen different? An empirical examination of major accounting firm audits of large clients. Journal of Empirical Legal Studies, 1(2), 263-300.

Eisenberg, T., Sundgren, S., \& Wells, M. T. (1998). Larger board size and decreasing firm value in small firms. Journal of financial economics, 48(1), 35-54.

Faleye, O. (2007). Classified boards, firm value, and managerial entrenchment. Journal of financial economics, 83(2), 501-529.

Fernando, G. D., Abdel-Meguid, A. M., \& Elder, R. J. (2010). Audit quality attributes, client size and cost of equity capital. Review of Accounting and Finance, 9(4), 363-381.

Firth, M., \& Smith, A. (1992). Selection of auditor firms by companies in the new issue market. Applied Economics, 24(2), 247-255.

Fuerman, R. D. (2003). Audit quality examined one large CPA firm at a time: Mid-1990's empirical evidence of a precursor of Arthur Andersen's collapse. Corporate Ownership \& Control, 2(1), 137-148.

Gaaya, S., Gaaya, S., Lakhal, N., Lakhal, N., Lakhal, F., \& Lakhal, F. (2017). Does family ownership reduce corporate tax avoidance? The moderating effect of audit quality. Managerial Auditing Journal, 32(7), 731-744.

Gertner, R., \& Kaplan, S. (1996). The value-maximizing board. University of Chicago. Retrieved from 
https://pdfs.semanticscholar.org/bc2d/f6f42c21078711349fcf2d9897b879545ca2.pdf

Ghazali, N. A. M., \& Weetman, P. (2006). Perpetuating traditional influences: Voluntary disclosure in Malaysia following the economic crisis. Journal of International Accounting, Auditing and Taxation, 15(2), 226-248.

Goodwin-Stewart, J., \& Kent, P. (2006). The use of internal audit by Australian companies. Managerial Auditing Journal, 21(1), 81101.

Hadad, M. D., Hall, M. J., Kenjegalieva, K. A., Santoso, W., \& Simper, R. (2011). Productivity changes and risk management in Indonesian banking: a Malmquist analysis. Applied Financial Economics, 21(12), 847-861.

Hair Jr, J. F., Hult, G. T. M., Ringle, C., \& Sarstedt, M. (2016). A primer on partial least squares structural equation modeling (PLSSEM): Sage publications.

Han, S., Kang, T., \& Rees, L. (2013). The association between institutional ownership and audit properties. Asia-Pacific Journal of Accounting \& Economics, 20(2), 199-222.

Haniffa, R. M., \& Cooke, T. E. (2005). The impact of culture and governance on corporate social reporting. Journal of Accounting and Public policy, 24(5), 391-430.

Hassan, C. H., Abdul, R. R., \& Mahenthiran, S. (2008). Corporate governance, transparency and performance of Malaysian companies. Managerial Auditing Journal, 23(8), 744-778.

Helen, K., Mandy, C., \& Sidney, G. (2007). Corporate governance and board composition: Diversity and independence of Australian boards. Corporate Governance: An International Review, 15(2), 194-207.

Herrmann, P., \& Datta, D. K. (2005). Relationships between top management team characteristics and international diversification: An empirical investigation. British Journal of Management, 16(1), 69-78.

IIARF. (2013). International Professional Practice Framework (IPPF). Altamonte Springs, FL: IIA Research Foundation.

Iwasaki, I. (2008). The determinants of board composition in a transforming economy: Evidence from Russia. Journal of corporate finance, 14(5), 532-549.

Jang, H.-Y. J., \& Lin, C.-J. (1993). Audit quality and trading volume reaction: A study of initial public offering of stocks. Journal of Accounting and Public policy, 12(3), 263-287.

Jensen, M. C. (1993). The modern industrial revolution, exit, and the failure of internal control systems. the Journal of Finance, 48(3), 831-880.

Jensen, M. C., \& Meckling, W. H. (1976). Theory of the firm: Managerial behavior, agency costs and ownership structure. Journal of financial economics, 3(4), 305-360.

Jiang, B., Frazier, G. V., \& Prater, E. L. (2006). Outsourcing effects on firms' operational performance: An empirical study. International Journal of Operations \& Production Management, 26(12), 1280-1300.

Johl, S. K., Kaur, S., \& Cooper, B. J. (2015). Board characteristics and firm performance: Evidence from Malaysian public listed firms. Journal of Economics, Business and Management, 3(2), 239-243.

Kao, M.-C., Lin, C.-Y., Hsu, P.-P., \& Chen, Y.-H. (2011). Impact of the financial crisis and risk management on performance of financial holding companies in Taiwan. World Academy of Science, Engineering and Technology, 74, 466-470.

Kaplan, S. E., Menon, K., \& Williams, D. D. (1990). The effect of audit structure on the audit market. Journal of Accounting and Public policy, 9(3), 197-215.

Kilduff, M., Reinhard, A., \& Mehra, A. (2000). Top management-team diversity and firm performance: Examining the role of cognitions. Organization science, 11(1), 21-34.

Kim, J.-B., Song, B. Y., \& Tsui, J. S. (2013). Auditor size, tenure, and bank loan pricing. Review of Quantitative Finance and Accounting, 40(1), 75-99.

Knechel, W. R., Krishnan, G. V., Pevzner, M., Shefchik, L. B., \& Velury, U. K. (2012). Audit quality: Insights from the academic literature. Auditing: A Journal of Practice \& Theory, 32(sp1), 385-421.

Kowalewski, O. (2016). Corporate governance and corporate performance: financial crisis (2008). Management Research Review, 39(11), 1494-1515.

Kunze, F., Boehm, S. A., \& Bruch, H. (2011). Age diversity, age discrimination climate and performance consequences-a cross organizational study. Journal of organizational behavior, 32(2), 264-290.

Leuz, C., \& Verrecchia, R. E. (2000). The economic consequences of increased disclosure. Journal of accounting research, 91-124.

Levrau, A., \& Van den Berghe, L. A. (2007). Corporate governance and board effectiveness: Beyond formalism. ICFAI Journal of Corporate Governance, 6(4), 58-85.

Lipton, M., \& Lorsch, J. W. (1992). A modest proposal for improved corporate governance. The business lawyer, 59-77.

Lowensohn, S., Johnson, L. E., Elder, R. J., \& Davies, S. P. (2007). Auditor specialization, perceived audit quality, and audit fees in the local government audit market. Journal of Accounting and Public policy, 26(6), 705-732.

Mahadeo, J. D., Soobaroyen, T., \& Hanuman, V. O. (2012). Board composition and financial performance: Uncovering the effects of diversity in an emerging economy. Journal of Business Ethics, 105(3), 375-388.

Malaysia, B. N. (2010). Minimum Standards for Prudential Management of Insurers (Consolidated ). Kuala Lumpur: Bank Negara Malaysia.

Matthews, K. (2013). Risk management and managerial efficiency in Chinese banks: a network DEA framework. Omega, 41(2), 207215.

Milliken, F. J., \& Martins, L. L. (1996). Searching for common threads: Understanding the multiple effects of diversity in organizational groups. Academy of Management review, 21(2), 402-433.

Mohamed, Z., Mat Zain, M., Subramaniam, N., Yusoff, W., \& Fadzilah, W. (2012). Internal audit attributes and external audit's reliance on internal audit: Implications for audit fees. International journal of auditing, 16(3), 268-285.

Mu, J., Peng, G., \& MacLachlan, D. L. (2009). Effect of risk management strategy on NPD performance. Technovation, 29(3), 170180.

Nagy, A. L., \& Cenker, W. J. (2002). An assessment of the newly defined internal audit function. Managerial Auditing Journal, 17(3), 130-137.

Nnadi, M., Efobi, U., \& Oledinma, A. (2017). Audit quality, family business and corporate governance mechanisms: the case of Morocco. Journal of Accounting in Emerging Economies(just-accepted), 00-00.

Nyameboame, J., \& Haddud, A. (2017). Exploring the impact of outsourcing on organizational performance. Journal of Global Operations and Strategic Sourcing, 10(3), 362-387. 
Otman, K. A. M. (2014). Corporate governance and firm performance in listed companies in the United Arab Emirates. Victoria University.

PAC. (2016). Public Accounts Committee (PAC)'s Report on Governance Management Control of 1Malaysia Development Berhad (1MDB). Retrieved from http://www.parlimen.gov.my: http://www.parlimen.gov.my/pac/review/docs-110-116.pdf

Padilla, A. (2002). Can agency theory justify the regulation of insider trading? Quarterly Journal of Austrian Economics, 5(1), 3-38.

Panasian, C., Prevost, A. K., \& Bhabra, H. S. (2003). Board composition and firm performance: The case of the Dey report and publicly listed Canadian firms. Retrieved from

Randøy, T., Thomsen, S., \& Oxelheim, L. (2006). A Nordic perspective on corporate board diversity. Age, 390(0.5428).

Ross, S. A. (1973). The economic theory of agency: The principal's problem. The American economic review, 63(2), 134-139.

Ruud, T. F. (2003). The internal audit function: An integral part of organizational governance. The Institute of Internal Auditors Research Foundation,(Jan, 2003), 37-96.

Saeidi, P., Sofian, S., \& Rasid, S. Z. B. A. (2014). A proposed model of the relationship between enterprise risk management and firm performance. International Journal of Information Processing and Management, 5(2), 70.

Schmidt, J. J. (2012). Perceived auditor independence and audit litigation: The role of nonaudit services fees. The Accounting Review, 87(3), 1033-1065.

SCM. (2017). Former Directors Jailed Six Months for Misleading Financial Disclosures to SC. Retrieved from https://www.sc.com.my/post_archive/former-directors-jailed-six-months-for-misleading-financial-disclosures-to-sc/

Shehata, N., Salhin, A., \& El-Helaly, M. (2017). Board diversity and firm performance: evidence from the UK SMEs. Applied Economics, 1-16.

Sil Kang, W., Kilgore, A., \& Wright, S. (2011). The effectiveness of audit committees for low-and mid-cap firms. Managerial Auditing Journal, 26(7), 623-650.

Solakivi, T., Töyli, J., Engblom, J., \& Ojala, L. (2011). Logistics outsourcing and company performance of SMEs: Evidence from 223 firms operating in Finland. Strategic Outsourcing: An International Journal, 4(2), 131-151.

Solakoglu, M. N., \& Demir, N. (2016). The role of firm characteristics on the relationship between gender diversity and firm performance. Management Decision, 54(6), 1407-1419.

Sundgren, S., \& Svanström, T. (2013). Audit office size, audit quality and audit pricing: evidence from small-and medium-sized enterprises. Accounting and Business Research, 43(1), 31-55.

Sundgren, S., \& Svanström, T. (2014). Auditor-in-charge characteristics and going-concern reporting. Contemporary accounting research, 31(2), 531-550.

Teoh, S. H., \& Wong, T. (1993). Perceived auditor quality and the earnings response coefficient. Accounting Review, 346-366.

Tilis, L. (2005). Audit quality and risk differences among auditors. SSRN.

Xu, Y., Zhang, L., \& Chen, H. (2017). Board age and corporate financial fraud: An interactionist view. Long Range Planning.

Yatim, P. (2010). Board structures and the establishment of a risk management committee by Malaysian listed firms. Journal of Management \& Governance, 14(1), 17-36.

Yermack, D. (1996). Higher market valuation of companies with a small board of directors. Journal of financial economics, 40(2), 185-211.

Yıldız, S., Baştürk, F., \& Boz, İ. T. (2014). The effect of leadership and innovativeness on business performance. Procedia-Social and Behavioral Sciences, 150, 785-793.

Zabri, S. M., Ahmad, K., \& Wah, K. K. (2016). Corporate Governance Practices and Firm Performance: Evidence from Top 100 Public Listed Companies in Malaysia. Procedia Economics and Finance, 35, 287-296.

Zimmerman, M. A. (2008). The influence of top management team heterogeneity on the capital raised through an initial public offering. Entrepreneurship Theory and Practice, 32(3), 391-414. networks. Transportation Research Part C: Emerging Technologies, 95(February), 346-362. https://doi.org/10.1016/j.trc.2018.07.022

James, S. L., Abate, D., Abate, K. H., Abay, S. M., Abbafati, C., Abbasi, N., Abbastabar, H., Abd-Allah, F., Abdela, J., Abdelalim, A., Abdollahpour, I., Abdulkader, R. S., Abebe, Z., Abera, S. F., Abil, O. Z., Abraha, H. N., Abu-Raddad, L. J., Abu-Rmeileh, N. M. E., Accrombessi, M. M. K., ... Murray, C. J. L. (2018). Global, regional, and national incidence, prevalence, and years lived with disability for 354 diseases and injuries for 195 countries and territories, 1990-2017: a systematic analysis for the Global Burden of Disease Study 2017. The Lancet, 392(10159), 1789-1858. https://doi.org/10.1016/S0140-6736(18)32279-7

Tan, H., Qin, L., Jiang, Z., Wu, Y., \& Ran, B. (2018). A hybrid deep learning based traffic flow prediction method and its understanding. Transportation Research Part C: Emerging Technologies, 90(January), 166-180. https://doi.org/10.1016/j.trc.2018.03.001

Taylor, K., Post, A., Hoshizaki, T. B., \& Gilchrist, M. D. (2019). The effect of a novel impact management strategy on maximum principal strain for reconstructions of American football concussive events. Proceedings of the Institution of Mechanical Engineers, Part P: Journal of Sports Engineering and Technology, 233(4), 503-513. https://doi.org/10.1177/1754337119857434 